II. RECENZJE I OMÓWIENIA

DOI: $10.17951 /$ et.2015.27.250

Anna Boruch

\title{
„PORTRET” CZAROWNiCY W ŚWIADOMOŚCI DZIECI
}

Bernadeta Niesporek-Szamburska, Stereotyp czarownicy i jego modyfikowanie. Na przykładzie tekstów dla dzieci i wypowiedzi dziecięcych, Katowice: Wydawnictwo Uniwersytetu Śląskiego, 2013, 222 s.

Książka Bernadety Niesporek-Szamburskiej Stereotyp czarownicy i jego modyfikowanie. Na przykładzie tekstów dla dzieci i wypowiedzi dziecięcych (Katowice 2013) stanowi próbę rekonstrukcji wyobrażenia czarownicy w tekstach pisanych z myślą o dzieciach i w wypowiedziach dzieci. Autorka postawiła sobie za cel ukazanie „trwałego jądra” tego wyobrażenia mitologicznego (funkcjonujaccego w ramie modalnej 'taki, jaki może być' i 'taki, jaki prawdopodobnie jest') oraz wskazanie komponentów kontekstowych i podlegających modyfikacji. Dokładniej, chodzi o odpowiedzi na pytania: 1) w jaki sposób dziecko, „przyjmując dużą liczbę przekazów kulturowych, związanych z tradycją i wierzeniami, kształtuje stereotypy", 2) czy świeżo wykrystalizowany stereotyp poddaje się modyfikacji, wreszcie - o to, 3) jak „mocowanie się" z materią semantyczną odzwierciedla się w sferze wypowiedzi językowych dzieci. Założenia przyjętej analizy, jak podkreśla sama autorka, wpisują się w nurt refleksji kognitywnej, zgodnie z którą nie istnieje ostra granica między wiedzą językową a niejęzykową, sam zaś język stanowi nie tylko narzędzie, ale też szczególny „skarbiec doświadczeń i przeżyć” przywołujący ogólną wiedzę o świecie (s. 10).

Książka jako całość została bardzo starannie zaplanowana. Zawiera solidną podbudowę teoretyczną, analizy tekstów drukowanych oraz podsumowania wyników badań własnych. W rozdziale pierwszym pt. Wokót stereotypu (s. 11-25) autorka koncentruje się na pojęciu stereotypu, prototypu i schematu, nawiązuje do bogatej literatury, m.in. do prac W. Lipmanna, H. Putnama, A. Schaffa, J. Bartmińskiego, Z. Mitosek, B. Weigl, A. Libury i innych. Przyjmuje, że stereotyp mimo zakładanej w definicjach odporności na zmiany - jednak zmianom podlega, gdyż jego modyfikacji sprzyjają czynniki takie, jak: osłabianie skojarzeń, tworzenie odmiennych profili, kreowanie nowych stereotypów wiązanych z tą samą nazwą. W rozdziale drugim - Konteksty kulturowe wyobrażenia mitologicznego czarownicy (s. 27-46) - prezentuje wyobrażenia czarownicy funkcjonujące w różnych kulturach. W rozdziale trzecim - Stereotyp czarownicy (s. 47-63) - podejmuje próbę odtworzenia i uporządkowania charakterystyk składających się na wyobrażenie czarownicy funkcjonujące w świadomości przeciętnego użytkownika języka. Roz- 
dział czwarty, zatytułowany Czarownica w tekstach dla dzieci (s. 65-117), zawiera przybliżenie wizerunku czarownicy wyłaniającego się z tekstów dla dzieci, kolejny zaś rozdział pt. Czarownica w wypowiedziach dzieci (s. 119-182) - obraz czarownicy w świetle danych eksperymentalnych pozyskanych od dzieci. W Zakończeniu (s. 183-186) dokonano podsumowania i zebrania najważniejszych wniosków dotyczących trwałości stereotypu. Całość pracy zamyka Indeks osobowy (s. 207-213), wykaz tabel i wykresów przedstawiających wyniki badań oraz zestaw rysunków wykonanych przez dzieci (s. 215-217), a także angielskie i rosyjskie streszczenia (s. 219-222).

Z ustaleń Bernadety Niesporek-Szamburskiej wynika, że stereotyp czarownicy łączy w sobie wiele podschematów i skryptów związanych z leczeniem, wróżeniem, czarowaniem i niesieniem zła. Nastąpiło w nim, jak pisze sama autorka, swoiste „zagnieżdżenie” i „zintegrowanie” niekiedy odmiennych, a innym razem podobnych cech. W pewnym sensie można nawet mówić o „stapianiu się pojęć - tworzeniu semantycznego amalgamatu ukrytego za jedną nazwą" (s. 36). Takie właśnie wieloaspektowe wyobrażenie odcisnęło swoje ślady w języku. Autorka szuka tych śladów zgodnie z metodologią lingwistyki kulturowej (etnolingwistyki w wersji lansowanej przez Jerzego Bartmińskiego i badaczy stereotypów, którzy za W. Lippmannem traktują je jako „obrazy w głowie ludzkiej”). Bada więc etymologię słowa, zestawia definicje słownikowe, nazwy synonimiczne, frazeologizmy i przysłowia związane z czarownica, by z danych systemowych (językowych) wydobyć cechy stereotypowe - żeńskość i związek z czarami. Zauważa, że cechy charakterystyczne składające się na stereotyp czarownicy, poświadczone w definicjach i nazwach synonimicznych (wiedźma, jędza, Baba-Jaga), akcentują jej brzydotę, starość i zło, utrwalone z kolei we frazeologizmach - także zachowania i wartościowanie postaci.

Zasadniczy stereotyp czarownicy, odtwarzany w książce na podstawie „faktów kulturowych", tj. demonologii ludowej, wiary, historii, obyczajowości oraz danych językowych obejmuje „domeny”, takie jak: nazwa i płeć, cechy kategoryzujące, wiek, wygląd (cechy zewnętrzne, zwłaszcza brzydota i kalectwo), atrybuty i postaci towarzyszące, cechy charakteru, skrypty stawania się czarownicą, wiek (przekonanie o jej nieśmiertelności). Autorka odtwarza także sposoby przemieszczania się (prototypowy środek lokomocji to miotła), lokacje w czasie i przestrzeni (miejsca odludne, sabaty), usposobienie czarownicy (złośliwość) oraz jej wartościowanie (czarownica bywa dobra lub zła, w przeważającej jednak mierze jest wartościowana negatywnie). W pracy scharakteryzowano również atrybuty czarownicy (miotła, kocioł jako symbol przemiany, różdżka i księga zaklęć, przedmioty o charakterze religijnym) oraz towarzysze życia (tzw. chowańce, demony przybierające postać jakiegoś zwierzęcia, ropucha, czarny kot). Sposoby ochrony przed czarownicą i sposoby jej rozpoznawania (na podstawie wyglądu lub zachowania) sytuują się na peryferiach stereotypu czarownicy.

Rozdział czwarty, w którym autorka podejmuje rozważania na temat obrazu czarownicy w baśni tradycyjnej, potwierdza utrwalone w zapisach wierzeń oceny czarownicy, jej specyficzne zachowania, miejsca przebywania, a także takie cechy, jak samotność czy odmienność. Z kolei baśń nowoczesna niesie ze sobą pewne modyfikacje, związane $\mathrm{z}$ wartościowaniem czarownicy (zwykle jest to ocena po- 
zytywna), z wyglądem (jest piękna). Zmianie uległ również zakres oddziaływań czarownicy na otoczenie.

W rozdziale piątym referowane są wyniki badań przeprowadzonych nad obrazem czarownicy w grupie (zróżnicowanej pod względem płci) 274 dzieci - w klasach I-VI na obszarze południowej Polski (w Goleszowie, Jaworznie i Katowicach).

Podczas badań zastosowano metodę ankiety i wywiadu. Postawione pytania brzmiały: Kim jest czarownica? Jak wyglada czarownica? Jakie cechy charakteru ma czarownica? Gdzie mieszka czarownica? Jakie przedmioty lub zwierzęta towarzysza czarownicy? Czy lubisz postać czarownicy? Powiedz, dlaczego ja lubisz / dlaczego jej nie lubisz? Skad znasz postać czarownicy? Najmłodsze dzieci uzupełniały swoje wypowiedzi rysunkami przedstawiającymi prawdziwa czarownicę. Grupę tę objęto również eksperymentem pedagogicznym, którego celem było sprawdzenie przyswajalności stereotypu poznanego w przekazie werbalnym w stosunku do wiedzy stereotypowej poznanej na gruncie społecznym i zbadanie trwałości stereotypu.

Autorka, podsumowując swoje badania, pisze, że z wypowiedzi dziecięcych wyłania się dobrze ukształtowany stereotyp czarownicy, na który składają się: „cechy kategoryzujące, czynności, wiązki cech wartościujących i związanych z wyglądem, lokalizacja oraz atrybuty postaci". Czarownica - według dzieci - to kobieta, która: czaruje, zjada dzieci, lata na miotle, jest zła, brzydka, ubiera się na czarno, mieszka $w$ strasznym domku lub $w$ domku z piernika, ma miotte, czarnego kota i charakterystyczny kapelusz. Z przeprowadzonych badań wynika też, że stereotyp czarownicy silniej utrwalił się u 9-latków niż u dzieci 7-letnich. Z kolei w wypowiedziach starszych dzieci (zwłaszcza wśród dziewczynek) widoczna jest większa tendencja do pozytywnego wartościowania. Dzieci starsze podawały również więcej cech precyzujących wygląd czarownicy niż dzieci młodsze, choć jednocześnie przypisywały jej mniej atrybutów. Zostały one „dopowiedziane” i ujawniły się w przekazie niewerbalnym (na rysunkach dzieci).

Przeprowadzone analizy (danych kulturowych, literatury dla dzieci, wypowiedzi dzieci) pozwoliły na sformułowanie przekonujących wniosków na temat badanego stereotypu, który - jak podkreśla autorka - jest niezwykle bogaty treściowo, zawiera podschematy i skrypty, ,zagnieżdżone” i ,zintegrowane”, stopniowane w semantycznym konglomeracie ukrytym za jedną nazwą. W stereotypie tym obecne są elementy wierzeń przedchrześcijańskich, wątków wierzeniowych i historycznych, niezwiązane ze sferą sacrum wątki życia społecznego; czerpie on z prototypowych wzorców czarownicy, wiedźmy i Baby-Jagi. W stereotypie ustabilizowały się cechy „mocne”, potwierdzone językowo (bycie kobietą, czarowanie, brzydota, złe usposobienie) i w tekstach (ocena, zachowanie, miejsca działania, odmienność, samotność, czarny kot, miotła). Kultura popularna do tych cech dodaje atrybuty: kocioł, różdżkę i księgę. Wymienione wyżej „wiązki cech” utrwalają profile czarownicy zawarte w baśni tradycyjnej. Z analiz wynika tė̇, że wizerunki czarownicy wyłaniające się z baśni nowoczesnej oraz z fantasy, a także tekstów medialnych są w stosunku do typowego obrazu znacząco zmodyfikowane. Zaobserwowano zmianę ewaluacji postaci - z negatywnej na pozytywną, zmienił się wygląd, przekształcony został zakres oddziaływań czarownicy na otoczenie. Konfrontacja stereotypowych obrazów - kulturowego i literackiego - z wyobrażeniem wyłaniającym się z wy- 
powiedzi dzieci (i uformowanym w duchu definicji kognitywnej J. Bartmińskiego), pozwoliła na wnioski co do trwałości stereotypu: obraz dziecięcy nie różni się znacząco od obrazu utrwalonego w języku i w kulturze. Różnice polegają jedynie na bardziej zmysłowym sposobie konceptualizacji czarownicy w wypowiedziach dzieci i negatywnych działań postaci, a także eksponowaniu obrazu Baby-Jagi w odpowiedziach na pytanie o prawdziwa czarownicę. Autorka stwierdza, że tendencja do modyfikowania stereotypu może wynikać ze znaku wartości, jaki niesie ze sobą wyobrażenie mitologiczne.

Staranne i atrakcyjnie opracowanie edytorskie zachęca do lektury i ją ułatwia. 